\title{
Ornamental Fish Diversity in the Jiadhal/Kumotiya River of Dhemaji District, Assam, India
}

\author{
Diganta Chetia $^{1 *}$, Begum Rehena Parvin² and Simanku Borah ${ }^{3}$ \\ ${ }^{1}$ Fish Nutrition Biochemistry and Physiology Division, Central Institute of Fisheries \\ Education, Mumbai 400061, India \\ ${ }^{2}$ Department of aquaculture, College of fisheries Science, Assam Agricultural University, \\ Raha, Nagaon 782103, Assam, India \\ ${ }^{3}$ Central Inland Fisheries Research Institute, Regional Centre, Housefed complex, \\ Guwahati 781006, Assam, India \\ *Corresponding author
}

\section{A B S T R A C T}

\section{Keywords \\ Ornamental fish, \\ Jiadhal/Kumotiya River, Dhemaji Assam \\ Article Info \\ Accepted: 24 September 2018 Available Online: 10 October 2018}

In the present study ornamental fish diversity in the Jiadhal/Kumotiya river of Dhemaji district, Assam, India was conducted during monsoon period from May 2018 to July 2018. A total of 44 species was recorded during the period of the study which belonging to 28 genera, 20 families and 9 orders. Highest species recorded from cyprinidae family. The present study recorded 38 species in IUCN -LC category, 3 species in NT, 1 species in $\mathrm{DD}, 1$ species in EN and 1 species in VU category.

\section{Introduction}

The nature's wonderful creation ornamental fishes are mean attractive colorful fishes with various characteristics, which are also known as living jewels and are kept in house as pets. In the recent years the ornamental fishes has become one of the major income sources for the small scale farmers and unemployment people of the world. The floodplains wetlands which are locally known as "Beels" is Assam plays a vital role in the diversity of locally available indigenous ornamentals fishes, as beels are biologically sensitive and provide nursery ground and ideal habitat for many ornamental and other fishes (Biswas et al., 1999). The river "Jiadhal" one of the sub tributary of the river Brahmaputra originated from Himalayan Mountains of Arunachal Pradesh at an altitude of $1247 \mathrm{~m}$ above the M.S.L.

After passing the hills area of Arunachal Pradesh the river enters into the plains area of Dhemaji district in Assam. From the Railway line to the Gogamukh the river is known as 
"Kumotiya" and from the Ghilamara P.W.D. road, the river is known as "Sampara". Out of total 1346 sq. km catchment area of the river Jiadhal 306 sq. km is in Arunachal Pradesh and 1040 sq. $\mathrm{km}$ is in Assam.

In India the North Eastern Region is one of the major hotspot for ornamental fish diversity in the world (Kottelat and Whitten, 1996). Including 32 ornamental fish species are available in the upper Assam districts like Tinsukia, Dibrugarh, Sibsagar and Jorhat (Pandey et al., 1998). Total 87 potential ornamental fish species are available in the state of Assam (Bhattacharjya et al., 2000).

Out of 217 fish species recorded in Assam 150 fish species have good ornamental value (Bhattacharjya et al., 2003). So far, in the North Eastern Region a total of 274 species has been recorded, of which 250 fish species have ornamental value, out of 250 species 187 recorded from the state of Assam (Mahapatra et al., 2004).

From the floodplain wetlands of upper Brahmaputra basin of Assam 62 ornamental fish species (Das and Biswas, 2009) and from the central valley of the river Brahmaputra 61 ornamental fish species (Sarma et al., 2004) has been recorded. The present study has been conducted to record the ornamental fish diversity in the Kumotiya region of the river Jiadhal.

\section{Materials and Methods}

The present study has been conducted based on monitoring the capture fishery sites of the river. Around 300 fish species were collected by visiting 15 local fish markets of the river basins and species were identified by following Jayaram (1999), Vishwanath et al., (2007) and Talwar and Jhingran (1991) nomenclature which were based on Fishbase (http://www.Fishbase.co). IUCN (2013) were followed for ascertaining the conservation status.

\section{Results and Discussion}

In the present study a total of 44 fish species belonging to 28 genera, 20 families and 9 orders has been recorded. Out of which 13 species belongs to cypriniformes order and cyprinidae family, 2 species belongs to cypriniformes order and botiidae family, 1 species belongs to cprinidontiformes order and aplocheilidae family, 1 species beloniformes order and belonidae family, 1 species belongs to siluriformes order and schilbeidae family, 4 species belongs to siluriformes order and bagridae family, 2 species belongs to siluriformes order and siluridae family, 1 species belongs to siluriformes order and clariidae family, 1 species belongs to siluriformes order and heteropneustidae family, 2 species belongs to synbranchiformes order and mastacembelidae family, 1 species species belongs to osteoglossiformes order and notopteridae family, 1 species belongs to perciformes order and badidae family, 2 species belongs to perciformes order and osphronemidae family, 1 species belongs to perciformes order and anabantidae family, 1 species belongs to perciformes order nandidae family, 5 species belongs to perciformes order and channidae family, 1 species belongs to perciformes order gobiidae family, 2 species belongs to perciformes order and ambassidae family, 1 species belongs to tetraodontiformes order and tetraodontidae family, and 1 species belongs to clupeiformes order and clupeidae family. All the species has been recorded are listed in table 1.

Out of 44 species has been recorded during the study period, 38 species enlisted as least concern (LC), 3 species as near threatened (NT), 1 species as endangered (EN), 1 species as vulnerable (VU) and 1 species as data deficient (DD). 
Table.1 Ornamental fish species was recorded in the river Jiadhal/Kumotiya of Dhemaji District, Assam, India during study period and their IUCN status

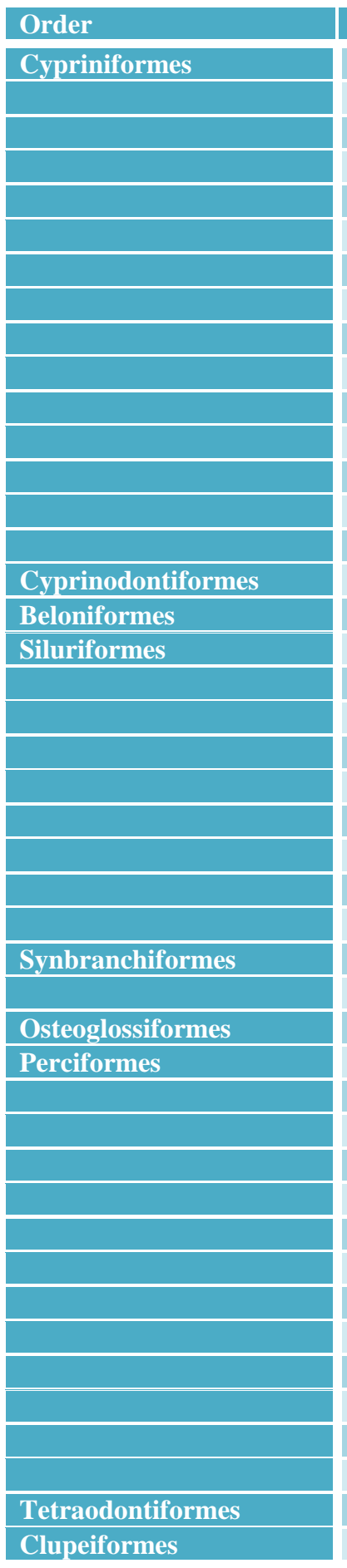

\begin{tabular}{|c|c|c|}
\hline Family & Name of the species & IUCN Status \\
\hline \multirow[t]{13}{*}{ Cyprinidae } & Amblypharygodon mola (Ham-Buch, 1822) & $\mathrm{LC}$ \\
\hline & Puntius sophore (Hamilton, 1822) & $\mathrm{LC}$ \\
\hline & Puntius conchonius (Ham-Buch, 1822) & $\mathrm{LC}$ \\
\hline & Puntius ticto (Ham-Buch, 1822) & $\mathrm{LC}$ \\
\hline & Puntius sarana (Hamilton, 1822) & LC \\
\hline & Puntius chola (Hamilton,1822) & LC \\
\hline & Puntius denisonii (F. Day 1865) & EN \\
\hline & Barilius bendelisis (Ham-Buch, 1822) & $\mathrm{LC}$ \\
\hline & Danio rerio (Ham-Buch, 1822) & LC \\
\hline & Esomus danricus (Ham-Buch, 1822) & $\mathrm{LC}$ \\
\hline & Rosbora daniconius (Hamilton,1822) & $\mathrm{LC}$ \\
\hline & Cirrhinus reba (Hamilton,1822) & $\mathrm{LC}$ \\
\hline & Labeo calbasu (Hamilton,1822) & LC \\
\hline \multirow[t]{2}{*}{ Botiidae } & Botia dario (Hamilton, 1822) & $\mathrm{LC}$ \\
\hline & Botia rostrata (Gunther, 1868) & VU \\
\hline Aplocheilidae & Aplocheilus panchax (Ham-Buch, 1822) & $\mathrm{LC}$ \\
\hline Belonidae & Xenentodon cancila (Ham-Buch, 1822) & LC \\
\hline Schilbeidae & Ailia coila (Hamilton, 1822) & NT \\
\hline \multirow[t]{4}{*}{ Bagridae } & Mystus cavasius (Ham-Buch, 1822) & LC \\
\hline & Mystus tengara (Ham-Buch, 1822) & $\mathrm{LC}$ \\
\hline & Mystus vittatus (Bloch,1794) & $\mathrm{LC}$ \\
\hline & Mystus gulio (Hamilton, 1822) & $\mathrm{LC}$ \\
\hline \multirow[t]{2}{*}{ Siluridae } & Ompok pabda (Hamilton,1822) & NT \\
\hline & Ompok bimaculatus (Bloach,1794) & NT \\
\hline Clariidae & Clarias batrachus (Linnaeus, 1758) & $\mathrm{LC}$ \\
\hline Heteropneustidae & Heteropneustes fossilis (Bloch, 1794) & $\mathrm{LC}$ \\
\hline \multirow[t]{2}{*}{ Mastacembelidae } & Macrognathus aral (Bloch-Schneider, 1801) & LC \\
\hline & Mastacembelus armatus (Lacepede, 1800) & $\mathrm{LC}$ \\
\hline Notopteridae & Notopterus notopterus (Pallas, 1769) & $\mathrm{LC}$ \\
\hline Badidae & Badis badis (Ham-Buch, 1822) & $\mathrm{LC}$ \\
\hline \multirow[t]{2}{*}{ Osphronemidae } & Trichogaster fasciatus (Bloch-Schneider, 1801) & $\mathrm{LC}$ \\
\hline & Colisa lalia (Ham-Buch, 1822) & $\mathrm{LC}$ \\
\hline Anabantidae & Anabas testudineus (Bloch, 1792) & DD \\
\hline Nandidae & Nandus nandus (Hamilton, 1822) & $\mathrm{LC}$ \\
\hline \multirow[t]{5}{*}{ Channidae } & Channa gachua (Hamilton, 1822) & LC \\
\hline & Channa marulius (Hamilton, 1822) & $\mathrm{LC}$ \\
\hline & Channa striatus (Bloch, 1793) & LC \\
\hline & Channa stewartii (Playfair, 1867) & $\mathrm{LC}$ \\
\hline & Channa punctatus (Bloch, 1793) & LC \\
\hline Gobiidae & Glossogobius giuris (Ham-Buch, 1822) & $\mathrm{LC}$ \\
\hline \multirow[t]{2}{*}{ Ambassidae } & Chanda nama (Hamilton, 1822) & $\mathrm{LC}$ \\
\hline & Chanda ranga (Hamilton, 1822 & $\mathrm{LC}$ \\
\hline Tetraodontidae & Tetraodon cutcutia (Hamilton, 1822) & $\mathrm{LC}$ \\
\hline Clupeidae & Gudusia chapra (Hamilton, 1822) & LC \\
\hline
\end{tabular}

LC-Least Concern; EN- Endangered; VU-Vulnerable; NT-Near threatened; DD-Data deficient.

Highlights

Study of ornamental fish diversity in the Jiadhal/Kumotiya river of Dhemaji District, Assam, India during monsoon period from May 2018 to July 2018.

A total of 44 species has been recorded which belonging to 28 genera, 20 families and 9 orders. 
In the threatened species red list of IUCN (2011), there are a total of 42 species listed under least concern (LC) category, 13 species under not evaluated (NE) category, 6 species under near threatened (NT) category and 1 species under data deficient (DD) category. Boro et al., (2014) has reported 49 ornamental fishes from the Sonkosh River, Bodoland Territorial Council, Assam, India belonging to 34 genera, 18 families and 6 orders. Of these 32 species recorded as least concern (LC), 7 species as endangered (EN), 6 species as not evaluated (NE), 4 species as near threatened (NT), 3 species as data deficient (DD) and 2 species as vulnerable category. Similar way Kumar and Sabitry (2012) has reported 62 ornamental fish species from the river island Majuli, Assam, India, belongs to 42 genera, 22 families and 9 orders out of which 42 species enlisted as least concern (LC), 13 species as not evaluated (NE), 6 species as near threatened (NT), and 1 species as data deficient category. Across Brahmaputra Valley of Assam 81 fish species was recorded by Goswami and Zade (2015) which comprises with both big and small fishes. Sharma et al., (2016) reported 66 ornamental fish species that are belongs to 48 genera, 21 families and 10 orders from the Barak valley fish markets, Assam, India. Of these species $78 \%$ belongs under least concern (LC) category, $14 \%$ under not evaluated (NE), $8 \%$ under near threatened (NT), 4\% under data deficient (DD) and $1 \%$ under vulnerable (VU). Rahman et al., (2014) has reported 28 ornamental fish species from North Guwahati, Assam, India which belongs to 17 families and 24 genera. Out which 16 species have high market value.

In the present study all the fish species recorded during the monsoon period from May to July. Out of the 44 fish species around $80 \%$ fishes has high ornamental value and all the fish species recorded has good food value except Tetradon cutcutia.
The present study indicates that the river Jiadhal/Kumotiya has rich indigenous ornamental fish diversity which also has food value too as the Brahmaputra river and its tributary are associated with wetlands (beels).

\section{Acknowledgement}

The authors are grateful to Indian Council of Agricultural Research- Central Institute of Fisheries Education, Mumbai for financial support.

\section{References}

Baro, D. C., Sharma, S., and Baishya, R. A. 2014. Status of ornamental fish diversity of Sonkosh River, Bodoland Territorial Council, Assam, India. Science vision, 14(1), 28-33.

Bhatacharjya, B.K., Sugunan, V.V. and Choudhury, M. 2000. Potential of Ornamental fishes of Assam. In. First Indian Science Congress, September 21-23, 2000, Indian Society of Fisheries Professionals, Chandigarh (Abstract), p.65.

Bhattacharjya, B.K., Choudhury, M. and Sugunan, V.V. 2003. Icthyofaunistic resources of Assam with a note on their sustainable utilization, In: Participatory approach for fish biodiversity conservation in Northeast India.

Biswas, S.P., Phukan, J. and Boruah, S. 1999. Prospects of development of ornamental fisheries in the northeast India, In: Kharbuli, B., Siyem, D. and Kayang, H. (Eds.), Proceedings of Workshop on People's participation in Biodiversity Conservation. 4-6 March 1999. Shillong, Meghalaya, India, p. 34-36.

Das, J.N. and Biswas, S.P. 2009. Current status and diversity of ornamental fishes in the floodplain wetlands of upper Brahmaputra basin. In: Kosygin, L. (Ed.), Wetlands of North East India: 
Ecology, Aquatic Bioresources and Conservation. Akansha Publishing House, New Delhi, p. 114-123.

Goswami, C., and Zade, V. S. 2015. Ornamental fish Diversity across Brahmaputra Valley of Assam. International Journal of Innovative Science, Engineering and Technology, 2(1), 547-549.

http:www.iucnredlist.org.in

Jayaram, K.C. 1999. The freshwater fishes of Indian region. Narendra Publishing House, Delhi, 471 pp.

Kottelat, M., and Whitten, T. 1996. Freshwater fishes of Western Indonesia and Sulawesi: additions and corrections. Hong Kong: Periplus Editions.

Kumar, D. M., and Sabitry, B. 2012. Diversity of ornamental fishes in the river island Majuli, Assam. Global Journal of Bio-Science and Biotechnology, 1(1), 81-84.

Mahapatra, B. K., Vinod, K., and Mandal, B. K. 2004. Ornamental Fish of North Eastern India-Its Distribution and Conservation Status. Environment and Ecology, 22(3), 674-683. NBFGR, Lucknow, India, p. 87 -105.
Pandey, A. K., Baruah, A., and Biswas, S. P. 1998. On the ornamental fish fauna in the Brahmaputra drainage system. Indian Journal of Fisheries, 45(1), 9597.

Rahman, S., Kakati, S., Choudhury, J. K., Sarma, P. C., Barua, E., and Dutta, A. 2014. Ornamental ichthyofaunal diversity of North Guwahati, Assam, India. IOSR Journal of Agriculture and Veterinary Science, 7(4), 10-13.

Sarma, S., Bhattacharjya, B. K., Zaildi, S. G. S., and Landge, A. 2004. Indigenous Ornamental Fish Biodiversity of Central Brahmaputra Valley Zone Assam. Journal of Inland Fisheries Society of India, 36(1), 29-35.

Sharma, B., Rout, J., and Swain, S. K. 2016. Inventory of indigenous ornamental fishes commonly found in Barak valley fish markets, Assam, India. Int. J. Pure App. Biosci, 4(1), 185-192.

Talwar, P. K. 1991. Inland fishes of India and adjacent countries (Vol. 2). CRC Press.

Vishwanath, W., Lakra, W. S., and Sarkar, U. K. 2007. Fishes of North East India, NBFGR. Lucknow, UP India, 264.

\section{How to cite this article:}

Diganta Chetia, Begum Rehena Parvin and Simanku Borah. 2018. Ornamental Fish Diversity in the Jiadhal/Kumotiya River of Dhemaji District, Assam, India. Int.J.Curr.Microbiol.App.Sci. 7(10): 3394-3398. doi: https://doi.org/10.20546/ijcmas.2018.710.393 